\title{
THE STRUCTURAL AND COMPARATIVE ANALYSIS OF MODERN AMERICAN FEATURE FILMS' SMALL SYNTAX IN TRANSLATION
}

\author{
Yuliia Pletenetska \\ National aviation university, Kyiv, Ukraine \\ yuliya.pletenetskaya@gmail.com
}

\begin{abstract}
The article is an in-depth research of the dubbed American feature films small syntax on the basis of the structural and comparative analysis of the original film texts and their Ukrainian translations. The paper considers the functioning of small syntax units with regard to their communicative intention, communicative reason and communicative validity. The author has proposed and described the structural classification of the English-speaking films small syntax models and their translation equivalents according to the morphological expression of the main word and the structure. The structural and comparative analysis of the small syntax of five American feature films and their Ukrainian equivalents has shown that the majority of word-combinations are simple, i.e. two-words (combination of two notional words or two notional words with the auxiliary part of speech) that is explained by film genres. The analysis presents also five types of formation of complex word-combinations and considers the productivity levels of film small syntax models. The article compares the main methods and techniques of the small syntax translation in the dubbed versions of American feature films and their frequency characteristics as well as introduces the reasons, varieties and conditions of the transformations usage. The results of the analysis have shown that audiovisual nature of the film text, differences in the rules of lexical-semantic and syntactic compatibility, various ways of expression traditional concepts, subjects and actions, the need for text synchronisation determined by the dubbed translation, defined the peculiarities of translation of the number of small syntax units.
\end{abstract}

Key words: small syntax; word combination; film translation; translation technique; American films; dubbed translation.

\section{Introduction}

On the face of it, the issue of translation of English small syntax into Ukrainian may seem to be unessential since this grammatical level is considered to be similar if not identical in both languages and the majority of structural types of word-combinations and their classifications have long been researched in the works of linguists and translators. The principal theoretical and practical problems connected with the investigation of the communicative effect of word-combination as well as its study in terms of dubbed translation of American feature films as a current direction of modern translation studies; have not been examined.

In recent research, the word-combination is considered as a second-place element on the fringes of syntax with the status of subcategory that structurally leans towards sentence and functionally - towards word. The later studies have offered to integrate syntactic theory into cognitive science, proving that syntactic theory is connected with the human mind. Such an understanding of the problem was the object of linguistic studies of Culicover (1999), Van Valin (2001), Zagnitko (2004). Assuming that, on the one hand, a word-combination names phenomena, characteristics and actions, the subjects of the objective reality, on the other hand, it is immediately involved in forming of messages i.e. in the communicative process. In this regard, small syntax was considered in a fewer number of studies represented by Sorokin (2001) and Romanets (2002). Therefore, the role of small syntax lies not just in the filling of any utterance model but also in the organisation of the communicative process and this process itself.

Not a big number of investigations were devoted to the issues of film translation either. Firstly, film phenomenon attracted attention of researchers interested in the problems of art and esthetics as special semiotic systems (Lotman, 1998; Deleuze, 2004). Nowadays film becomes a matter of interest of linguists (Gorshkova (2006), Konkulovskyj (2011), Lukyanova (2011), Malkovych (2016), Snetkova (2009), Chaume (2008), Keane (2003), Kinberg (2010). The researchers discuss dubbing and subtitling as ways of film translation, analyse their advantages and disadvantages; interlanguage synchronism; genesis of film translation based on the theatrical translation. Thus, with the emerging role of audiovisual communication, constant growth in the film popularity, a kind of cinematographic boom, it seems reasonable to study small syntax as an integral part of the communicative process, of modern American speech, based on the American feature films.

Therefore, the research is aimed at analysing and comparing of modern American small syntax structure in the dubbed translation of American feature films of different genres based on the description of syntactic constructions of English visuals small syntax as independent units and the self-contained system oriented to the process of communication.

This article is based on the $\mathrm{PhD}$ thesis of the same author, where the peculiarities of small syntax translation in the dubbed American film texts are analysed (Pletenetska, 2013) as well as on the material of the article following the thesis (Pletenetska, 2015, pp. 284-287). The scientific novelty of this study is in: 
1) considering the ways of formation of complex word combinations chosen from film dialogues and the level of their correspondence to the translated structures; 2) generalised transformation approach to the translation methods used in dubbed Ukrainian versions of American film texts small syntax word combinations and the reasons that call for such changes.

\section{Methods}

In the course of the work with the help of continuous sampling method we have selected 2736 small syntax units from five American feature films: "Alice in Wonderland", "Pirates of the Caribbean: On stranger tides", "Meet the parents: little Fockers", "Fast Five", "Sex and the city 2", with total duration over 20 hours and the same quantity of their Ukrainian equivalents, professionally dubbed Ukrainian translations. The units of small syntax were examined using translation comparison method of films and their translated versions' analysis involving the elements of transformation analysis to study all the possible transformations while translating the small syntax constructions. The main elements of small syntax analysis in the original and translated film texts are morphologic-syntactic analysis, linguistic-stylistic analysis (to compare the structures of contrasted languages and to establish common and different features in the Ukrainian and English languages' unit systems). To add to the objectivity of the results obtained the elements of the quantitative method were used.

\section{Results}

The study of small syntax syntactic constructions in the context of language and translation allows us to make some conclusions on the specificity of small syntax, its extraordinary informative value in general and the small syntax of English visuals and the peculiarities of its translation, in particular.

The choice of syntactic construction while performing certain informative tasks occurs, first of all, with regard to its communicative intention, communicative reason and communicative validity. The crucial link of English visuals' small syntax of both English and Ukrainian languages is the nominal construction that due to its semantic-functional peculiarities is able not only to be the component of the sentence being this or that element but to play an entirely independent role in the process of communication. The syntactic unit under examination is the optimal structure for the concentration of extremely large volume of information and therefore, it is capable not only to be the building material for the sentence but also to form the perspective of informative message. The functional opposition of word-combination and sentence is minimised in nominal constructions and the functions of these syntactic formations go far beyond the boundaries of the usual nomination or constructive entrance to this or that syntactic structure. Nominative construction can exist independently from the sentence and perform the communicative function in certain spheres of human life. Besides its effective use in different messages that are the integral part of the names of different higher educational establishments, enterprises, organisations; names of films, books, journals, monographs, articles, headlines; terminological systems; advertising system of headings, texts and slogans, it is also used in the colloquial language of films. The direct orientation of nominal construction on the material organisation and the communicative process makes it functionally valid syntactic formation - the operational link in the system of communicative units of the Ukrainian and English languages. The volume of nominative construction in the investigated films makes $72,3 \%$ in the original and $64,3 \%$ in translation.

Along with substantial predominance of nominative constructions due to the objective need of communicative process, the functioning of the other types of the small syntax constructions appeared to be rather active. Thus, there were distinguished $15,4 \%$ of verbal constructions with dependent noun, pronoun, adjective and numeral words. From all the investigated small syntax word-combinations 19, $4 \%$ were rendered by verbal constructions in translation that testifies to the higher communicative value of the Ukrainian verb. Other 12, $3 \%$ of English visuals small syntax constructions and 16, $3 \%$ of their translated equivalents were almost equally divided between adjectival, numeral, pronominal and adverbial wordcombinations.

The structural and comparative analysis of the small syntax of five American feature films and their Ukrainian equivalents according to the classification of Zagnitko (2004) has shown that the majority of word-combinations are simple, i.e. two-words (combination of two notional words or two notional words with the auxiliary part of speech) (pp. 65-66). Their translated equivalents usually retain the structure of English word-combinations: to get the country - відібрати країну, men from the train - люди з поїзда, the decline of the aristocracy - занепад аристократії, a piece of jewelry - ювелірні вироби, vicious ruтоr злісні чутки, filthy pirate - бідний nipam, a moment of misunderstanding - момент непорозуміння, retired florist - квіткар на пенсіі. 
The organisation of this or that word-combination in terms of structure in our opinion is defined by its genre. Genre classification is the basis for forming certain audience expectations and the reason for choosing the criteria of film dialogue organisation. The table below shows the conclusions we came to while comparing the structure of the small syntax of different genres' films.

Table 1

The number of simple and complex word-combinations of different genres' films

\begin{tabular}{|c|l|c|c|}
\hline The name of the film & \multicolumn{1}{|c|}{ Genre } & $\begin{array}{c}\text { The number of } \\
\text { simple word- } \\
\text { combinations (\%) }\end{array}$ & $\begin{array}{c}\text { The number of } \\
\text { complex word- } \\
\text { combinations } \\
(\%)\end{array}$ \\
\hline "Alice in Wonderland" & $\begin{array}{l}\text { Fairy tale, family, } \\
\text { adventure }\end{array}$ & 44,4 & 55,6 \\
\hline $\begin{array}{c}\text { "Pirates of the Caribbean: On } \\
\text { stranger tides" }\end{array}$ & Adventure, action & 66 & 34 \\
\hline $\begin{array}{c}\text { "Meet the parents: little } \\
\text { Fockers" }\end{array}$ & Family comedy & 51 & 49 \\
\hline $\begin{array}{c}\text { "Fast Five" } \\
\text { "Sex and the city 2" }\end{array}$ & Action, criminal thriller & 59 & 41,8 \\
\hline
\end{tabular}

The language of the film "Pirates of the Caribbean: On stranger tides", for example, is bright, stylistically coloured mostly due to the use of metaphors, irony, allusion phrases. Its genre, however, adventure, action defines rather simple structural organisation of word-combinations. In this film, the emphasis is made on the quick change of settings, scenery, the great number of special effects, that border on reality. It is aimed at creating the feeling of keeping the audience in suspense and emotional stress whereas attempts to understand long sentences with overstructured word-combinations will hardly contribute to this.

The feature film "Alice in Wonderland" - a fairy tale, family, adventure according to the genre is characterised by the interesting, colourful, diverse language in part due to the text of the fairy tale of the same name. Stylistically it is characterised by bookish language, common and colloquial lexis, poetic lexis. Sometimes archaisms are used that adds some solemnity and grand style. This stylistic colouring determines to some extent the structural model. In the film "Pirates of the Caribbean: On stranger tides", for example, the number of simple word-combinations significantly prevails over the number of complex wordcombinations and makes $66 \%$, whereas the film "Alice in Wonderland" is characterised by the greater number of complex word-combinations, that make up $56 \%$ of the total number of film's word-combinations.

The film "Meet the parents: little Fockers" (comedy) is the third part of films "Meet the Parents" and "Meet the Fockers".

Comedies are generally known to be full of metaphors, allusions, hyperbole, pun, irony, euphemism, slang, jargonism, culture-biased words, specific humour peculiar to some culture, nationality, the direct transcoding of which often remains confusing for translators and hence for the final recipient.

All these means of humorous effect can cause translation losses if the translator fails to understand the message and find appropriate equivalents. However, it is not always that one should look for them since the translation equivalence does not always mean adequate rendering of the content of the film, what, in our opinion, is the main task in the translation of the film text.

It is generally known, that the success of American comedies' translation oriented on the young audience, is often explained by the presence of colloquial language, slang words, jargon words, a certain level of vulgarity and humour.

It is the concern of film critics and film fans to judge the success of American comedy "Meet the parents: little Fockers", however, the translation of the film seems to be successful if to believe O. Mikchalev (famous Russian simultaneous interpreter and film translator) that the translation is good if the viewer does not notice it. Having looked through the great number of film translation reviews and comments, we came across the only remark, concerning its name ("Little Fockers" - in the original).

The structure of the small syntax of the film is almost the same in both languages since the number of simple word-combinations is nearly equal to the number of complex ones, $51 \%$ and $49 \%$ correspondingly.

The film "Fast Five" is the fifth part of the same name's film. The definite film genre, - a thriller, an action, determines the presence of special effects. During the whole film something occurs, explodes, jumps, runs, crashes, turns over, burns or shoots. These entire cars' twists and turns, races, shootings done by film 
characters are accompanied by the perfect soundtrack erasing boundaries between the audience and the heroes making everyone feel its incredibly fascinating atmosphere.

The plot is thoughtful, interesting, humorous by no means vulgar but the language is not characterised by the overload of complex word-combinations $(40 \%)$ that is understood since the spectacularity is crucial for thriller films. In addition, the number of word-combinations selected for study is three times less than the number of word-combinations taken from the other studied films and makes 204 units. Although- humour is subtle, the language is not: the speech of the characters is full of specific jargon words, dialects and invective vocabulary. Cars, races, safes of the advanced design and other ultramodern equipment determine the use of a great number of terminological elements.

The film "Sex and the city 2" (2010) is a melodrama and comedy film, the continuation of the film "Sex and the city" (2008) that was shot based on the Darren Star's TV series and upon the book by Candace Bushnell. The standard and simple plot and the easy film determine the structural characteristics of the small syntax language: $58 \%$ (357) simple word-combinations. Stylistically it is mostly common and colloquial language.

\section{Discussion}

As we can see from the table only in the film "Alice in Wonderland" directed by Tim Burton, the number of complex word-combinations prevails over the number of simple ones. The simple organisation of the language of other films is determined mostly by the specificity of the genre: criminal thriller, melodrama and comedy do not presuppose complex structure of the film dialogue. The other factor is cultural - the difference between the American and Ukrainian mentality that influences relatively simple character of American speech in the film (Pletenetska, 2015, p. 285).

Having analysed complex word-combinations (1227), we found five ways of their forming:

1. The extension of noun-adjective word-combination by one or several determinating words: biometric palm scanner - біометричний ручний годинник, former federal agent - колишній федеральний агент, chubby, patient Jewish girl - пухкенька євреєчка, the beautiful Irish hunting knife - ірландський мисливський ніж;

2. The extension of noun-noun word-combination by determinating word: delicious anniversary meal смачна вечеря, bioidentical estrogen сrеат - крем з біоідентичним естрогеном, a lifetime supply of antidepressants - антидепресантів на усе життя;

3. The extension of verbal word-combination by nouns with or without prepositions: to spice up your love life - додати перию в любовне життя, to break you out of jail - визволяти тебе, to be a burden on mother - висіти в мами на шиї, adjectives: to keер your hands and mouth busy - зайняти рота й руки, to make the dying slow - щоб смерть була повільною, to paint the roses red-троянди перефарбувати;

4. The extension of adjective word-combinations by the forth word: to endure a boring old married couple - терпіти нудну сімейну пару;

5. The extension of the noun by the complex numeral or numeral word-combination: eight-and-a-halfinch tread-протектор $21 \mathrm{~cm}$, ten tons of top-of-the-line security - 10 тонн безвідмовного захисту.

The structure of translated equivalents is different by the ways of forming from original wordcombinations. During the translation of the mentioned above complex word-combinations, the translators use full translation preserving the structure of the original word-combination or partial translation, reduction, permutation or functional change. These transformations are usually determined by three factors: the difference in rules of lexico-semantic and syntactic compatibility and the restrictions imposed on the translation by the high-quality dubbed version.

Syntactic assimilation or full translation is a type of "zero" transformation that occurs in cases when in the original language and the language of translation exist in parallel constructions. While studying the translation of small syntax constructions of American feature films it was concluded that in $33 \%$ of cases full translation was used; the translator managed to preserve the original structure of the word-combination. The productivity of structural models of small syntax in American films was also investigated. By the productivity on the level of the model its quantitative characteristic is meant, therefore, we regard those models to be productive, following the form of which long series of word-combinations are created.

The most productive model of full translation in all the films under study appeared to be the model of attributive word-combination $(\mathrm{A}+\mathrm{N})$. In fact, this model is the most productive one in various other sublanguages, among them: linguistics, medicine, economics, mathematics and others. Therefore, under the conditions of syntactic similarity, attributive word-combinations are the most stable within the sublanguage of the film. The role of the attributive adjectives in word-combinations is to specify the content marking the notion expressed by the core noun according to the additional characteristic. 
In $90,68 \%$ cases the original word-combinations and their translated equivalents have the same grammatical expression, i.e. the structure of small syntax of the mentioned above model does not change in translation. The lexical content of the original word-combinations, as a rule, is rendered in a linear fashion: fabulous reviews $\rightarrow$ чудові статmi, or $\mathrm{A}+\mathrm{N} \rightarrow \mathrm{A}+\mathrm{N}$

In separate cases in translation non-linear rendering of original word-combinations is observed: progesterone cream - крем з прогестероном.

In $9,32 \%$ of cases such transformations as narrowing, extension, functional change and permutation were used.

Due to the analytical character of the English language and the tendency to implication in EnglishUkrainian film translations extensions of word-combinations with the addition of semantic components: an uneventful second - одна, не варта уваги, мить, would reasonably occur more often. However, the necessity of adherence to the time-code of the dialogue and the rules of the dubbed translation caused more often the use of narrowing as a method of syntactic transformation on the level of word-combination. During narrowing as a rule semantically less meaningful component of word-combination is omitted: spice market базар. Sometimes the differences in names of subjects and objects in two languages caused narrowing: homeless man - жебрак, changing room - примірочна, straight man - натурал (Pletenetska, 2015, p. 287).

$67 \%$ cases of all the word-combinations were translated with the help of partial translation. Functional change makes up the largest number of transformations (28, $4 \%$ ). Many examples in the investigated category are connected with the translation of English prepositional word-combinations of various structures from simple: $\mathrm{N}+$ prep. $+\mathrm{N}$ - a team of drivers - zpyna водіïв, chief of police - шеф nоліuіï, the methods of the Portuguese - методи португальиів, form of flattery - форма лестощів, waste of time- втрата часу, the smell of the sea - запах моря, art of deception - мистеитво обману, a lot of light - багато світла; to more complex: $\mathrm{N}+$ prep. $+\mathrm{N}+\mathrm{Adv}$. - a couple of weeks ago - кілька тижнів тому, $\mathrm{N}+\mathrm{A}+\mathrm{N}-$ couple of high-end cars - кілька дорогих тачок, $\mathrm{A}+\mathrm{N}+$ prep. $+\mathrm{N}-$ a whole pool of testosterone - повний басейн тестостерону; $\mathrm{V}+\mathrm{N}+$ prep. $+\mathrm{N}$ - to explore the vow of silence - досліджувати обітницю мовчання; $\mathrm{N}+$ prep+pron. $+\mathrm{N}-$ rest of our lives - peшту нашого життя; $\mathrm{A}+\mathrm{A}+\mathrm{N}+$ prep. $+\mathrm{N}+\mathrm{N}+\mathrm{conj} .+\mathrm{N}-a$ progressive, global city of commerce, culture and style - прогресивне міжнародне місто торгівлі, культури та стилю, Num.+prep.+pron.+N - three of my men-mроє моїх людей, four of those cars -4 таких тачки, Num. $+\mathrm{N}+$ prep. $+\mathrm{A}+\mathrm{N}-$ ten tons of top-of-the-line security - 10 тон безвідмовного захисту, $\mathrm{A}+\mathrm{N}+$ prep.+pron. $+\mathrm{N}$ - the biggest celebration of our life - найбільше свято нашого життя. All the word-combinations are translated without prepositions due to synthetic structure of the Ukrainian language i.e. by means of combination of the grammatical meaning with the lexical meaning within the word. Grammatical meaning of the Ukrainian language is expressed through the wide system of noun declension and verb conjugation with the help of flections, inflectional affixes and interchange of sounds. The English language due to the lack of such a rich morphology delivers grammatical meanings by means of the developed preposition system. The given word-combinations have the constructions with of-preposition that are translated by nouns and the combination of adjective and noun, pronoun and noun in genitive case singular or plural.

It is worth noting in this category the translation of nominal prepositional word-combination $(\mathrm{N}+$ prep. $+\mathrm{N})$, for example: a part of the plan - твіи задум: apart from the absence of preposition in translation (that is explained by the synthetic character of the Ukrainian language that is not inclined to prepositional formations), it is also evident the lexico-semantic change of all the full components of the word-combination as well as the change of morphological status of the noun a part into the pronoun mвiü. This transformation seems to be reasonable as it delivers the meaning to the full extent. The director shows this episode (the talk between Captain Jack Sparrow and another pirate Joshamee Gibbs) from a far distant view that limits the translator only to the length of the dialogue.

In the translation of word combination your engagement party - ваші заручини святкувати, the functional change of the noun party into the verb святкувати is justified. Let us have a closer look at this word-combination in the context: It's why they've all come. This is your engagement party - Томy ж $i$ зібрались. Ваші заручини святкувати. In response to the imaginative question of the first utterance why they've all come one might expect to hear the infinitive verb form, furthermore, in both languages. The important is the articulation match of the end of the utterance - the end of the verb святкувати and original noun party, since this is the close shot utterance. According to the number of syllables, the second Ukrainian utterance exceeds the English equivalent. The full equivalent and adapted form would be something close to: Це свято ваших заручин (the same number of syllables - 8).

During the translation of the word-combination three of my tarts - три мигдальні коржики the functional change of the possessive pronoun my into the adjective мигдальні is used, which stems from the 
original version of Lewis Carroll's fairy tale "Alice in Wonderland" where the issue is about macaroon goods. The whole version of the utterance: Someone has stolen three of my tarts! - Xтось у мене три мигдальні коржики вкрав, which the queen cries in anger at her servants, explains us the use of permutation by placing the word вкрав at the end of the utterance the translator achieves the best consonance with the noun tarts, that the queen dwells so furiously in close shot.

The transformation of functional change and narrowing is used in the word-combination your fancy rabbit - свої фантазї of the utterance: I can't be bothered with your fancy rabbit now - Hе марнуй мого часу на свої фантазї, люба. Although the structure of the sentence and its lexico-semantic filling undergo some changes (pron. $+\mathrm{A}+\mathrm{N} \rightarrow$ pron. $+\mathrm{N}$ ), its content is full, the translator only eliminates the repetitions, since Alice reminds about the white rabbit in waistcoat three times during two episodes. The translation of this word-combination is well adapted to the original version. The open and close vowels are successfully synchronised.

During the translation of the word-combination to defibrillate myself - дефібрилятор осcurs the change of the morphological status of the verb into the noun as well as the reduction of the reflexive pronoun myself, that is explained by the absence in the Ukrainian language of the word with this meaning. Despite the difference in the sets of lexico-grammatical words' classes, the translator achieves the accordance with articulation: Stay calm, Mr. Jinx. I am going to defibrillate myself - Спокійно, Джінкс. Це буде дефібрилятор, зрозумів? - this is the way Jack Burns addresses his cat, feeling the heart attack.

During the translation of the word-combination the elite task-force for the DSS - елітний загін дипломатичної служби the functional change is observed. The complex noun task-force is turned into the noun загін and the abbreviation DSS (Defense Security Service) - into the nominal word combination дипломатична служба. It is reasonable to decipher abbreviation, though, not accurate since in the Ukrainian language the corresponding acronym is absent and in accordance with the translating rules, this abbreviation is translated by the corresponding full form of the word-combination. However, in the analysed translation this transformation is determined by the necessity of utterance synchronisation.

The original nominative word-combination a piece of jewelry is translated by the adjective-noun wordcombination ювелірні вироби because of the difference in traditional names of the objects in both languages. The other question is the accuracy of the choice of lexico-semantic equivalent. It is about the episode when Carry and Big exchange the presents to the wedding anniversary and Carry having received the big TV set being tactful in her disappointment says: Well, a piece of jewelry would've been nice - Hу, ювелірні вироби, теж непогано. The investigated word-combination sounds rather officially in this case. The use of the word-combination якісь прикраси instead would have been more natural stylistically, conformed the number of syllables, and indefinite pronoun якісь is consonant with the noun a piece.

While translating the word-combination a little reminder - вузлик на згадку occurs the change of the structure from $\mathrm{A}+\mathrm{N}$ to $\mathrm{N}+$ prep. $+\mathrm{N}$. The Ukrainian diminutive noun вузлик renders the connotation of the adjective a little - the best, both word-combinations have the same number of syllables what is important for the synchronisation of a close shot.

In $18,1 \%$ cases of translation, narrowing was used i.e. the reduction in the number of components of the translated word-combination compared to the original one. The reduction is mainly caused by the differences in traditional names of objects, stylistic context conditions or utterance i.e. phonetic synchronisation. Therefore, the translation of word-combinations a fishing net-невід, travel guide - путівник, the main highway - автомагістраль, homeless man - жебрак, changing room - примірочна, straight man натурал, wedding ring - обручка, soul mates - подруги, to have dinner - повечеряти requires the use of narrowing due to the traditional difference in the names of subjects, objects and actions.

The extension of the word-combination (the addition of one or more components to the wordcombination in translation) was used in $2,6 \%$ of cases. The same number of word-combinations required permutation during translation.

The translation of the word-combination a blue caterpillar - гусінь блакитна in case of permutation meets the demands of dialogue synchronisation (And there's a blue caterpillar - A ще була гусінь блакитна) of the close shot. The adjective блакитна and the noun caterpillar have almost the same set of open and close vowels, whereas the use of common word order $(\mathrm{A}+\mathrm{N})$ in translation would shatter the illusion of truth.

Consequently, with the prevailing of nominative constructions $(72,3 \%$ in the original text and $64,3 \%$ in the translated version) due to the objective needs of the communicative process the functioning of other types of small syntax constructions appeared to be rather active. There were identified $15,4 \%$ of verbal constructions with the dependent noun, pronoun, adjective and numeral words. Of all the investigated small syntax word-combinations $19,4 \%$ were translated with the help of verbal constructions that testifies to the 
higher communicative value of Ukrainian verb. The other 12,3\% English small syntax constructions and $16,3 \%$ of their translated equivalents were almost equally divided between adjectival, numeral, pronominal and adverbial word-combinations.

\section{Conclusions}

The structural and comparative analysis of the English visuals small syntax units enables us to conclude that only in the feature film "Alice in Wonderland" (fairy tale, family, action) the number of complex wordcombinations exceeds the number of simple ones. In other films the number of simple small syntax constructions slightly ("Mett the parents: little Fockers") or significantly ("Fast Five") exceeds the number of complex that, on the one hand, shows some communicative orientation of specific genre that determines simple structure organisation of word-combinations and, on the other hand, - the orientation on literaryesthetic influence and some pragmatic effect that is revealed by the greater implicitness of the verbal text and hence its simplification that is compensated by the other channels of information transmitting, provided by the audiovisual character of film.

Complex word-combinations were formed with the help of extension: noun-adjective wordcombinations were extended by one or several determinating words, noun-noun word combinations - by one determinating word, verbal word-combinations - by nouns with or without prepositions, adjectival wordcombinations - by the forth word, noun - by the complex numeral or numeral word-combination.

Comparative analysis of American feature films small syntax structures and their dubbed Ukrainian equivalents enables us to reveal peculiarities and difficulties of dubbed translation determined by the necessity of synchronisation of actors' articulation with visuals with simultaneous coordination of speech tempo and duration of separate utterances. Taking into account the mentioned difficulties adequate translation requires from the translator special skills of paraphrasing the original text with preserving the content of the dialogues.

Audiovisual nature of the film text, differences in the rules of lexical-semantic and syntactic compatibility, various ways of expression traditional concepts, subjects and actions, the need for text synchronisation determined by the dubbed translation defined the peculiarities of translation of the number of small syntax units. The method of full translation was used in $30 \%$ of translation cases. The structures of original word-combinations were marked by the great diversity $(\mathrm{A}+\mathrm{N}, \mathrm{N}+\mathrm{N}$, comp. $\mathrm{A}+\mathrm{N}, \mathrm{N}+$ prep. $+\mathrm{N}, \mathrm{V}+\mathrm{N}$, pron. $+\mathrm{N}$, pron. $+\mathrm{A}, \mathrm{V}+$ prep. $+\mathrm{N}$, pron. $+\mathrm{A}+\mathrm{N}, \mathrm{Num} .+\mathrm{A}+\mathrm{N}, \mathrm{Adv} .+\mathrm{A}+\mathrm{N}, \mathrm{A}+\mathrm{A}+\mathrm{N}, \mathrm{V}+$ pron. $+\mathrm{A}, \mathrm{V}+\mathrm{A}+\mathrm{N}$, $\mathrm{V}+$ pron. $+\mathrm{N}+$ prep. + pron., $\mathrm{A}+$ conj. $+\mathrm{A}+\mathrm{N}, \mathrm{N}+$ prep. $+\mathrm{N}+\mathrm{N}$, prep. $+\mathrm{N}+$ prep.+pron. $+\mathrm{N}, \mathrm{V}+\mathrm{Adv} .+\mathrm{Adv} .+$ prep. $+\mathrm{N})$. Word-combinations formed by the first two models appeared to be the most productive in the language of the modern American film. Among partial translation, the transformations of functional change (the change of lexical-semantic or morphological status of one or several original word-combination elements) and the narrowing as methods of syntactic transformations on the level of word-combinations were used most often. The better understanding of syntactic changes often required the explanation of lexical-semantic changes that occur in the structure of the word-combination during translation.

The study of small syntax in the communicative aspect and the language of film dialogues aimed at finding specific features of general-text categories has nowadays substantial perspectives for the applicationoriented investigations for both specialists in translation and the researchers in other spheres of knowledge linguists, culture specialists, psychologists and sociologists. The detailed study of the film as a form of modern literary text, the rules of certain grammatical film text phenomena, the problems of film text pragmatic adaptation, estimation criteria of translation quality are important to achieve the higher level of film translations in Ukraine helping to promote the development of Ukrainian translation mastery in general and the Ukrainian language and culture in particular.

\section{References:}

Chaume, F. (2008). Teaching synchronization in a dubbing course. Some didactic proposals. In J. Dias Cintas (Ed.), The Didactics of Audiovisual Translation (pp. 129-140). USA, John Benjamins Publishing Company. https://doi.org/10.1075/btl.77

Culicover, P. W. (1999). Syntactic Nuts:Hard Cases, Syntactic Theory, and Language Acquisition. Oxford, England: Oxford University Press.

Deleuze, G. (2004). Kino: Kino 1. Obraz-dvizhenija; Kino 2. Obraz-vremya [Film: Film. Image-motion; Film 2. Image-time] (B. Skuratova, Trans). Moscow, Russia: Ad Marginem.

Gorshkova, V.Ye. (2006). Teoreticheskije osnovy protsessorientirovannogo podhoda $k$ perevodu kinodialoga: na materiale sovremennogo frantsuzskogo kino [Theoretical Basics of Process-oriented Approach to the Translation of Film dialogue: based on the material of modern French films]. Unpublished doctoral dissertation, Irkutsk State Linguistic University, Irkutsk, Russia.

Keane, Ch. (2003). Hot Property: Screenwriting in New Hollywood. New York, USA: Berkley Books. Retrieved August 13, 2017 from https://www.amazon.com/Hot-Property-Christopher-Keane/dp/0425190404

Kinberg, S. (2010). Screenwriting. Retrieved August 13, 2017 from www.screenwriting.info 
Konkulovskyj, V. V. (2011). Do problem perekladu kinotekstiv komedijnogo zhanru [On Problems of Comedy Film Texts Translation]. Visnyk LNU im. Tarasa Shevchenka, 16 (227), Chast. I, 35-40.

Lotman, Yu. M. (1998). Ob iskusstve: Struktura khudozhestvennogo teksta. Semiotika kino I problemy kinoestetiki [On Art: Structure of literary text. Semiotics of Film and Problems of Film esthetics] (pp. 315-323). Saint Petersburg, Russia: Iskusstvo.

Lukianova, T. G. (2011). Teoretychni aspecty kinoperekladu z anglijskoi na ukrainsku movu [Theoretical aspects of film translation from English into Ukrainian]. Visnyk Chersonskogo natsionalnogo universytetu, 973, 183-187.

Malkovych, T. I. (2016). Pryntsypy vidtvorennya dialogichnogo movlennya v anglo-ukrajinskomu perekladi [Principles of Translation of Dialogic Speech in English-Ukrainian translation]. Published candidate dissertation, Kyiv National Taras Shevchenko University, Kyiv, Ukraine. Retrieved from http://scc.univ.kiev.ua/abstracts/?PAGEN_1=27

Pletenetska, Yu. M. (2013). Malyy syntaksys suchasnogo anglomovnogo videoryadu ta yogo vidtvorennya ukrainskoiu movoiu (na materiali khudozhnih fil'miv SSHA [English-Speaking Films Small Syntax and its Rendering into Ukrainian (Based on the Material of the USA Films)]. Unpublished candidate dissertation, South Ukrainian National Pedagogical K.D. Ushynskyj University, Odesa, Ukraine.

Pletenetska, Yu. M. (2015). Syntaksychne upodibnennya slovospoluchen' anglomovnogo videoryadu ta jogo dubl'ovanyh perekladiv [Syntactic adaptation of the small syntax constructions of English-language films and their dubbed translations]. Naukovi zapysky Natsional'nogo universytetu “Ostroz'ka akademija”. Serija: Philologichna, 54, 284-287.

Romanets, N. I. (2002). Konstruktsii malogo syntaksysu v suchasnii rosijs'kij movi [Small Syntax Constructions in Modern Russian Language]. Unpublished candidate dissertation, National University of Dnipropetrovs'k, Dnipropetrovs'k, Ukraine.

Snetkova, M. S. (2009). Lingvostilisticheskije aspekty perevoda ispanskih kinotekstov: na materiale ruskih perevodov ispanskih kinofilmov L. Bunyuelya "Viridiana" I P. Almodovara "Zhenshchiny nag rani nervnogo sryva" [Lingvostylistic Aspects of Spanish Film Text Translation: based on the material of Russian translations of Spanish films of L. Buñuel "Virtidiana" and P. Almodovar "Women on the Verge of a Nervous Breakdown"]. Unpublished candidate dissertation, Moscow State M.V. Lomonosov University, Moscow, Russia.

Sorokin, S. V. (2001). Systema mikrosyntaksysu turetskoji movy [System of Microsyntax of Turkish]. Unpublished candidate dissertation, Kyiv National Taras Shevchenko University, Kyiv, Ukraine.

Van Valin, R. D. (2001). An Introduction to Syntax. Cambridge, England: Cambridge University Press. https://doi.org/10.1017/cbo9781139164320

Zagnitko, A. P. (2004). Osnovy ukrayinskogo teoretychnogo syntaksysu. [The Basics of Ukrainian Theoretical Syntax]. Gorlivka, Ukraine: GDPIM. 